\title{
Role of Folate, Cobalamin, and Probiotics in COVID-19 Disease Management [Letter]
}

\section{Dayab Asad' \\ Syed Hasan Shuja $\mathbb{D}^{2}$}

'Jinnah Sindh Medical University, Karachi, Sindh, Pakistan; ${ }^{2}$ Dow Medical College, Karachi, Sindh, Pakistan
Correspondence: Syed Hasan Shuja Dow Medical College, Dow University of Health Sciences, Baba-e-Urdu Road, Karachi, 74200, Pakistan

Tel +923200250770

Email hasanshuja6@gmail.com

\section{Dear editor}

Recently, a review titled, "COVID-19: Vaccine Delivery System, Drug Repurposing and Application of Molecular Modeling Approach"1 was published by Abd El Hadi et al in the prestigious journal Drug Design, Development and Therapy. We would like to acknowledge the remarkable work done by the authors and congratulate them on a successful publication.

The review discussed the origin, transmission, epidemiology, and possible treatment methods for Covid-19, which require further observation in pre-clinical and clinical trials. The strategies for therapeutics included drug repurposing of various drugs, such as polymerase inhibitors, protease inhibitors, interferons, and statins. Moreover, nutritional interventions for managing the disease were also among the suggestions. ${ }^{1}$ However, we feel that the review has certain lackings in the nutritional interventions section. As such, we would like to make some contributions.

In the nutritional intervention segment, the authors mentioned various nutrients and minerals, such as vitamins A, vitamin B2, B3, vitamin C, vitamin D, zinc, selenium, and pyrithione, that have shown significant results in the management of the disease. ${ }^{1}$ Nevertheless, the use of vitamins B9, B12 probiotics, and magnesium, which have also exhibited a positive impact on the prognosis of the infection, was not highlighted.

Multiple studies have shown that folic acid inhibits the binding of the SARS-CoV-2 spike proteins, which blocks the entry of the virus into the cell. One study suggested that vitamin B9 acted as an inhibitor of the furin enzyme, and thus prevented the virus from entering the cell, and another preprint reported that the derivatives of Folic acid, especially 5-methyl tetrahydrofolic acid and tetrahydrofolic acid, have a strong binding affinity against the SARS-CoV-2., ${ }^{2,3}$

Furthermore, the use of probiotics interferes with ACE2, which is the chief host cell receptor. Hence, it prevents the entry of the virus into the cell. Probiotics also repress cytokines and at the same time increase innate immunity. This inhibition of cytokines by probiotics may play a vital role in preventing acute respiratory distress syndrome (ARDS). ${ }^{4}$

Vitamin B12 in combination with magnesium and vitamin D has also shown promising results by decreasing the severity and the need for oxygen and intensive care. $^{5}$ 
It is evident from the aforementioned studies that there is a significant role of vitamins B9, B12, magnesium, and probiotics in managing the Covid-19 disease. Further trials should be conducted to enhance the power of these results.

\section{Disclosure}

The authors report no conflicts of interest for this communication.

\section{References}

1. Abd El Hadi SR, El-Deen EE, Bahaa MM, Sadakah AA, Yassin HA. COVID-19: vaccine delivery system, drug repurposing and application of molecular modeling approach. Drug Design Dev Ther. 2021;15:3313. doi:10.2147/DDDT.S320320
2. Sheybani Z, Dokoohaki MH, Negahdaripour M, et al. The role of folic acid in the management of respiratory disease caused by COVID-19. 2020. doi:10.26434/CHEMRXIV.12034980.V1

3. Kumar V, Kancharla S, Jena MK. In silico virtual screening-based study of nutraceuticals predicts the therapeutic potentials of folic acid and its derivatives against COVID-19. Virusdisease. 2021;32 (1):29-37. doi:10.1007/S13337-020-00643-6

4. Shakoor H, Feehan J, Mikkelsen K, et al. Be well: a potential role for vitamin B in COVID-19. Maturitas. 2021;144:108. doi:10.1016/J. MATURITAS.2020.08.007

5. Tan CW, Ho LP, Kalimuddin S, et al. A cohort study to evaluate the effect of combination Vitamin D, Magnesium and Vitamin B12 (DMB) on progression to severe outcome in older COVID-19 patients. medRxiv. 2020. doi:10.1101/ 2020.06.01.20112334.

Dove Medical Press encourages responsible, free and frank academic debate. The content of the Drug Design, Development and Therapy 'letters to the editor' section does not necessarily represent the views of Dove Medical Press, its officers, agents, employees, related entities or the Drug Design, Development and Therapy editors. While all reasonable steps have been taken to confirm the content of each letter, Dove Medical Press accepts no liability in respect of the content of any letter, nor is it responsible for the content and accuracy of any letter to the editor.

Drug Design, Development and Therapy

\section{Publish your work in this journal}

Drug Design, Development and Therapy is an international, peerreviewed open-access journal that spans the spectrum of drug design and development through to clinical applications. Clinical outcomes, patient safety, and programs for the development and effective, safe, and sustained use of medicines are a feature of the journal, which has also been accepted for indexing on PubMed Central. The manuscript management system is completely online and includes a very quick and fair peer-review system, which is all easy to use. Visit http://www. dovepress.com/testimonials.php to read real quotes from published authors. 